\title{
Jurnal Riset Biologi dan Aplikasinya
}

https://journal.unesa.ac.id/index.php/risetbiologi

\section{Pengembangan LKPD Berbasis Search, Solve, Create and Share (SSCS) untuk Melatih Keterampilan Proses Sains pada Materi Arthropoda Kelas X SMA}

\author{
The Development LKPD Based on Search, Solve, Create and Share (SSCS) \\ to Train Process Skills in Arthropoda Materials of X-Grade Senior High School \\ Amanda Ivana Sanchia, Ulfi Faizah* \\ Jurusan Biologi, Fakultas Matematika dan Ilmu Pengetahuan Alam, Universitas Negeri Surabaya
}

\section{History Article}

Received: 13 Juli 2018

Approved: 9 Januari 2019

Published: Maret 2019

Kata Kunci:

LKPD, (Seacrh, Solve, Create and Share), Arthropoda, keterampilan proses skill

\section{Keywords:}

student worksheet, (Seacrh, Solve, Create and Share) SSCS, Arthropod, scientific process skill

\begin{abstract}
Abstrak
Keterampilan proses sains dapat dilatihkan dengan menerapkan konsep biologi yang berorientasi pada pendekatan saintifik untuk mengembangkan kompetensi ilmiah. Pada proses pembelajaran Lembar Kegiatan Peserta Didik (LKPD) sangat penting guna menunjang aktivitas pembelajaran peserta didik. Arthropoda merupakan kelompok hewan invertebrata yang sering dijumpai di sekitar kita dan merupakan salah satu materi yang dipelajari di Biologi kelas X. Tujuan penelitian ini untuk menghasilkan LKPD berbasis Search, Solve, Create and Share (SSCS) pada materi Arthropoda yang layak secara teoretis yang ditinjau dari hasil validitas dan layak secara empiris yang ditinjau dari aktivitas peserta didik, hasil belajar peserta didik, dan respons peserta didik. Penelitian ini merupakan penelitian pengembangan yang mengacu pada model 4D (define, design, develop, disseminate). Tahap pengembangan dilaksanakan di Jurusan Biologi selanjutnya diujicobakan kepada 20 peserta didik MAN Sidoarjo dengan rancangan one group pre-test-post-test. Hasil penelitian menunjukkan bahwa LKPD berbasis SSCS yang dikembangkan termasuk kategori sangat valid. Penilaian berdasarkan aktivitas peserta didik memperoleh nilai 96.66\% dengan kategori praktis artinya hampir semua peserta didik melakukan kegiatan pada LKPD berbasis SSCS dan respons peserta didik memperoleh nilai $96.95 \%$ dengan kategori sangat praktis. Simpulan penelitian ini menunjukkan bahwa LKPD berbasis SSCS materi Arthropoda untuk melatihkan keterampilan proses layak secara teoretis dan empiris.
\end{abstract}

\begin{abstract}
Scientific process skills can be trained by applying biological concepts oriented on the scientific approach to developing scientific competence. In the learning process student worksheet is important in order to support the learning activities of learners. Arthropoda is a group of invertebrate animals that can be found around us. This topic is learned in Class X Biology. This research aimed to produce a Search-based, Solve, Create and Share (SSCS) LKPD on the theoretically feasible Arthropoda material reviewed from results of validity and empirical worth in terms of the activities of students, learning outcomes of students, and the response of students. This research was developmental research that refers to the $4 \mathrm{D}$ model (define, design, develop, disseminate). The Development phase was implemented in Biology Department then was tested to 20 students of MAN Sidoarjo with one group pre-test-post-test. Student learning outcomes were analyzed using the gain score. The results showed that the student worksheet developed in this research was valid. Assessment based on student's activity score $96.66 \%$ with categories of very practical means that almost students did the activity on SSCS-based LKPD and student's response got value $96.95 \%$ with a very practical category. Based on this data it can be concluded that LKPD of SSCS Arthropoda material to train the process of skill theoretically and empirical.
\end{abstract}

How to cite: Sanchia, A. A \& Faizah, U. (2019). Pengembangan LKPD Berbasis Search, Solve, Create and Share (SSCS) untuk Melatih Keterampilan Proses Sains pada Materi Arthropoda Kelas X SMA. Jurnal Riset Biologi dan Aplikasinya. 1 (1): 9-17.

\footnotetext{
\& Correspondence Author:

Jalan Ketintang Gedung C3 Lt. 2 Surabaya 60231, Indonesia

E-mail: ulfifaizah@unesa.ac.id 


\section{PENDAHULUAN}

Pendidikan tidak hanya semata-mata berkaitan dengan aspek kognitif saja melainkan metode yang digunakan dalam proses pembelajaran juga harus sesuai dengan tujuan pembelajaran yang ingin dicapai. Pada proses pembelajaran dengan Kurikulum 2013 berorientasi pada pendekatan saintifik yang menekankan pada pemberian pengalaman dan praktik, karena pembelajaran yang menekankan pada pemberian pengalaman secara langsung dengan melakukan pengamatan objek akan mempermudah peserta didik dalam mengklasifikasikan makhluk hidup serta data yang diperoleh akan lebih valid (Lepiyanto, 2016). Keberhasilan dalam ketercapaian tujuan pembelajaran juga tidak dapat dipisahkan dari sumber belajar. Penggunaan sumber belajar mampu menunjang kegiatan proses belajar mengajar yang penting bagi peserta didik untuk membangun pengetahuannya sendiri dengan penggunaan Lembar Kegiatan Peserta Didik (LKPD) (Trianto, 2011).

Salah satu inovasi model pembelajaran yang dapat digunakan oleh guru dalam proses pembelajaran pada materi mengklasifikasikan makhluk hidup yaitu dengan model Search, Solve, Create and Share (SSCS) yang berbasis problem solving (Febriyanti, 2014). Model SSCS merupakan model pembelajaran yang berpendekatan pemecahan masalah yang memiliki empat tahapan yaitu search, solve, create and share (Lartson, 2013).

Materi Arthropoda merupakan salah satu materi yang dipelajari di Biologi kelas X SMA dan merupakan Filum terbesar yang anggotanya tersebar luas. Arthropoda dapat dijumpai dengan mudah di lingkungan sekolah, sehingga kegiatan pengamatan dapat dilakukan dengan memanfaatkan lingkungan sekolah sebagai sumber belajar (Nursa'diyah, 2014). Dengan demikian pembelajaran pada materi Arthropoda dirancang untuk mengajak peserta didik melakukan kegiatan pengamatan anggota filum Arthropoda dan mendeskripsikan ciri morfologi pada tiap kelas yang tergabung dalam filum Arthropoda. Oleh karena itu, materi ini merupakan salah satu materi yang membutuhkan keterampilan proses.

Berdasarkan hasil dari angket yang telah diberikan kepada 3 guru dan 35 peserta didik di MAN Sidoarjo menyebutkan bahwa pembelajaran pada materi filum Arthropoda belum dilatihkan keterampilan proses sains karena pada kegiatan pembelajaran belum menerapkan keterampilan proses sains. Selain itu, media dan sumber belajar yang digunakan menjadi kendala untuk guru dalam penyampaian materi. Kendala tersebut disebabkan karena kurangnya media dan sumber belajar yang mengarah pada kegiatan pengamatan hewan secara langsung. Akibatnya peserta didik kurang aktif dan tidak termotivasi pada proses pembelajaran.

Berdasarkan hal tersebut, pembelajaran melalui observasi atau pengamatan langsung dapat melatihkan keterampilan proses peserta didik. Salah satu model pembelajaran yang dapat melatihkan keterampilan proses yaitu model pembelajaran SSCS. Model pembelajaran SSCS ini, berorientasi pada pemecahan masalah yang terdiri dari empat tahap yaitu mengidentifikasi masalah, membuat rumusan masalah, melakukan pengamatan, dan mengkomunikasikan. Keunggulan model SSCS yakni dapat mengajak peserta didik aktif dalam kegiatan pembelajaran dengan melakukan pengamatan langsung untuk mencapai kecakapan kognitif, afektif, dan psikomotornya kreativitasnya (Febriyanti, 2014).

Bertolak dari uraian di atas, maka diperlukan adanya pengembangan LKPD berbasis Search, Solve, Create and Share (SSCS) untuk melatih keterampilan proses sains pada materi arthropoda kelas X SMA layak secara teoretis yang ditinjau dari hasil validitas dan layak secara empiris yang ditinjau dari aktivitas peserta didik, hasil belajar peserta didik, dan respons peserta didik.

\section{METODE}

Penelitian ini merupakan penelitian pengembangan untuk menghasilkan LKPD Berbasis SSCS yang layak secara teoretis yang ditinjau dari hasil validasi dan layak secara empiris yang ditinjau dari aktivitas peserta didik, hasil belajar peserta didik, dan respons peserta didik pada materi Arthropoda. Penelitian ini menggunakan model pengembangan four-D Models (4D) yang terdiri dari empat tahapan yakni Define (Pendefinisian), Design (Perancangan), Develop (Pengembangan), dan Disseminate (Penyebaran). Sasaran penelitian ini adalah Lembar Kegiatan Peserta Didik (LKPD) berbasis Search, Solve, Create and Share (SSCS) untuk melatihkan keterampilan proses pada materi arthropoda yang diujicobakan pada 20 peserta didik kelas X MIA 1 di MAN Sidoarjo.

Penelitian ini menggunakan metode validasi, observasi dan respons, serta tes dalam pengumpulan data. Instrumen yang digunakan berupa lembar validasi LKPD, lembar observasi keterlaksanaan aktivitas peserta didik meliputi 
Aktivitas Peserta Didik menggunakan LKPD berbasis SSCS dan Keterampilan Proses Sains Peserta Didik, lembar pre-test dan post-test dan lembar angket peserta didik. LKPD dinyatakan layak apabila nilai validasi $\geq 70 \%$, aktivitas peserta didik akan dinyatakan layak jika mendapat persentase $\geq 70 \%$, peserta didik dinyatakan tuntas apabila dapat mencapai KKM 75, respons peserta didik dinyatakan tuntas apabila mendapat persentase $\geq 70 \%$. Peningkatan skor pre-test dan post-test dianalisis menggunakan gain score.

\section{HASIL DAN PEMBAHASAN}

Peneliti mengembangkan LKPD berbasis SSCS pada materi Arthropoda untuk melatihkan
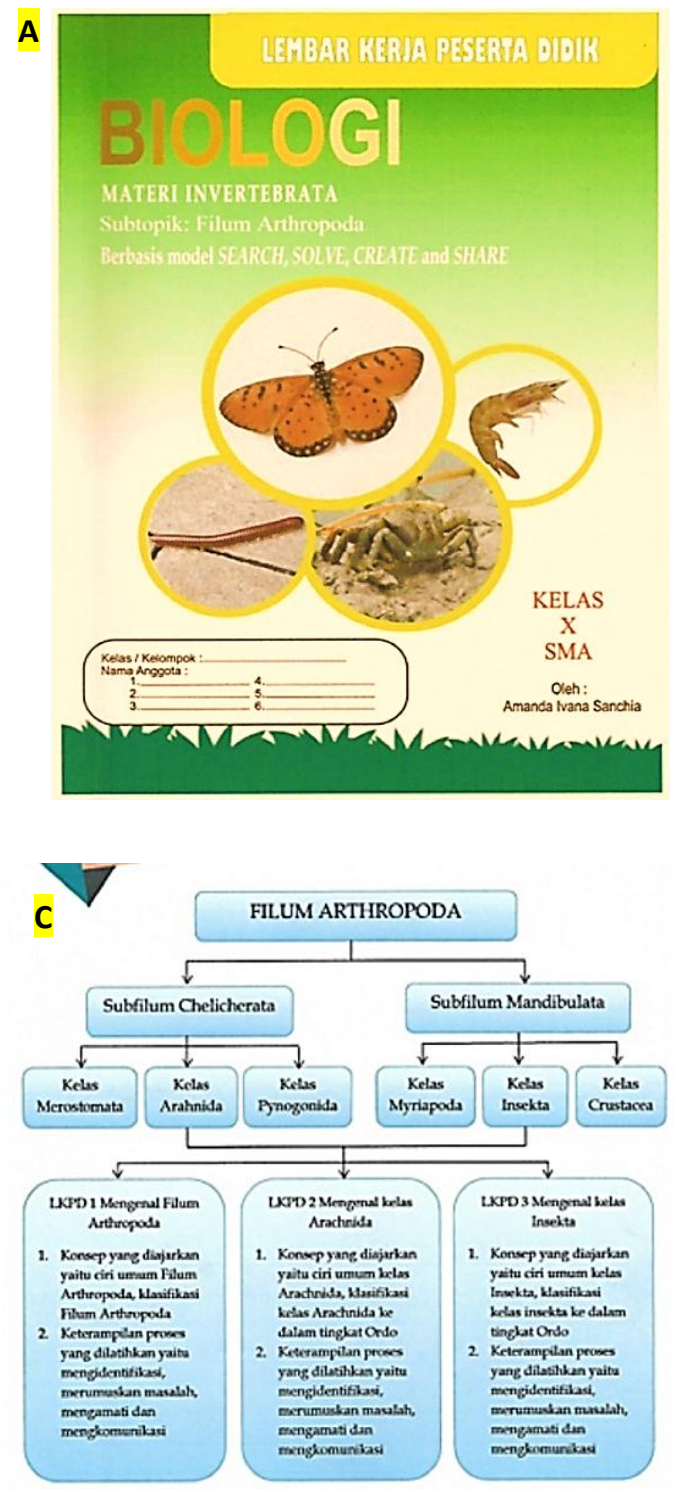

Gambur 1. Skema konscp dan keterampilan proses yang dilatihkan pasa LXPD

Kegiaun SSCS puda LKPD harus dilakennakan secara runtut mulai dari LKPD 1 hingga 3. Adapun talupan kegiaten SSCS dalam LKPD adalah setugai berikut (Gambur 2). keterampilan proses yang terdiri atas tiga bagian yaitu LKPD 1 yakni dengan topik filum Arthropoda, LKPD 2 yakni dengan topik Insekta dan LKPD 3 dengan topik Arachnida. Karakteristik LKPD yang dihasilkan adalah penggunaan SSCS untuk materi Arthropoda (Gambar 1. A-D).

Pada Lembar Kegiatan Peserta Didik berbasis SSCS yang dikembangkan dilengkapi dengan beberapa fitur-fitur yang memudahkan peserta didik dalam penggunaan LKPD berbasis SSCS serta memudahkan peserta didik untuk memahami konsep dalam pembelajaran Filum Arthropoda (Tabel 1).

B

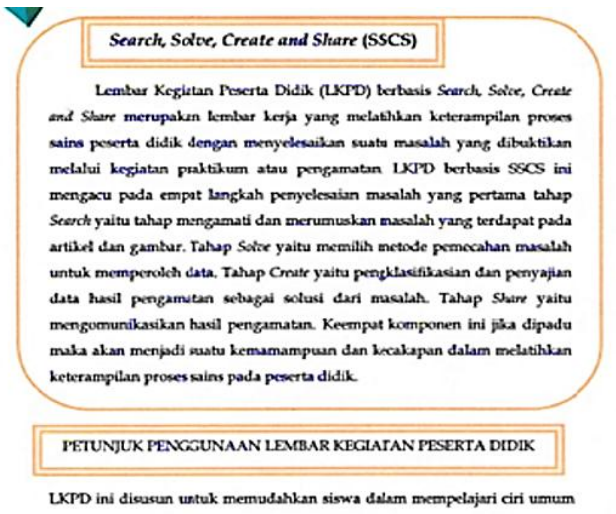
Filum Arthropota, Masiflessi Flum Arthropota, ciri umum kelus lnseckte. Arechrids, Crustacea dan Myriapoda, Klasifikasi kelas Insekta, Arachnida. Crustacea dan Myriapoda. Kegiaten poda LKPD dilakakan mengacu pada model

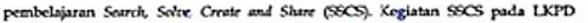
ditandai dengan simbol berama merah ( $\square$ ).

Disamping ita kegiutan dalana LKPD ini melatil siswa untuk daput dengan baik melakukan keterarpian proses sins (mxegidentifikas, merumuskan pertanyaan, mengamati din menghomunilasa) yang ditandad dengan symbed

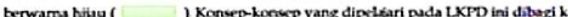
dalam 3 LKTD yang berbedh (Gambur 1 ).

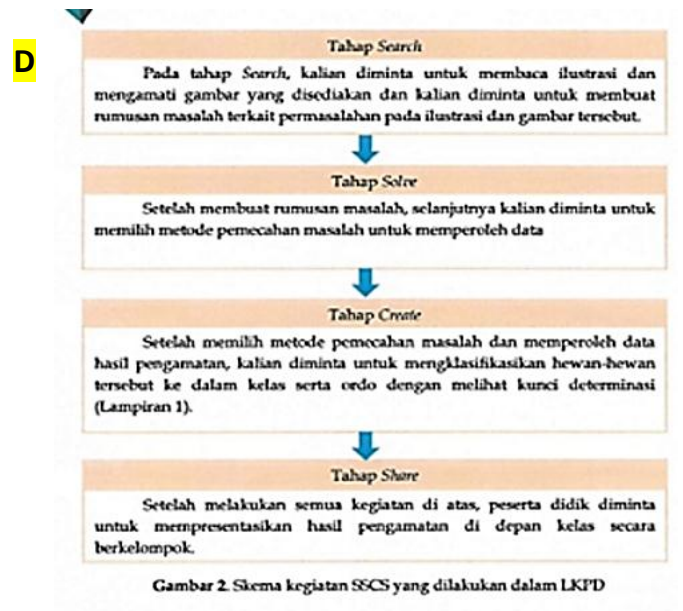

Pada UXPD ini, dikngkapi dengan gambar tuntuan dan kund determinasi pods lampiran untuk memtuntu siswa dilum melakukan pengamatan Selian itu. LKPD diknghopi dengan kund jawatan sehingga mempermudah guru untuk menandu peserta didik. Apatila terduput altematif jawaban, maka guru dapat menggunukannya sebugai plitisan sesuai dengan jawabun peserta didik

Gambar 1. Profil LKPD. A. Cover LKPD, B. Peta Konsep LKPD,

C. Tahapan SSCS pada LKPD, D. Kunci Identifikasi pada LKPD 
Hasil pengembangan berupa LKPD berbasis SSCS pada materi Arthropoda. Berdasarkan hasil analisis data validasi LKPD berbasis SSCS termasuk kedalam kategori sangat valid dengan modus 4 (Tabel 2).

Aktivitas yang diamati, yaitu meliputi 15 aktivitas pembelajaran menggunakan LKPD berbasis SSCS terhadap 20 peserta didik. Berdasarkan hasil analisis data aktivitas peserta didik, diperoleh hasil rekapitulasi rata-rata aktivitas peserta didik dengan menggunakan LKPD berbasis SSCS praktis sebesar 96,66\%. Hasil aktivitas peserta didik merupakan jumlah peserta didik yang melakukan aktivitas menggunakan LKPD berbasis SSCS disajikan pada tabel berikut (Tabel 3).

Berdasarkan Tabel 3 diketahui bahwa keempat aspek keterampilan proses yang dituntut dalam LKPD telah mendapatkan kategori yang baik yaitu diperoleh persentase sebesar 91,25\% yang tergolong dalam kategori aktif.

Berdasarkan Tabel 5 diketahui bahwa keempat aspek indikator untuk keterampilan proses yang dituntut dalam LKPD mendapatkan kategori yang baik yaitu diperoleh persentase sebesar 91,25\% yang tergolong dalam kategori aktif.

Hasil dari rekapitulasi respons peserta didik dapat diketahui dari lembar angket yang dibagikan kepada peserta didik. Berdasarkan hasil analisis respons peserta didik terhadap 20 peserta didik, diperoleh hasil rata-rata penilaian sebesar 96,95\% termasuk dalam kategori sangat praktis. Hasil sikap direkapitulasi dalam bentuk tabel berikut ini (Tabel 5).

Ketercapaian indikator dan ketuntasan hasil belajar peserta didik mengacu pada KD 3.9 dan KD 4.9. Untuk mengetahui ketercapaian indikator dan ketuntasan hasil belajar peserta didik maka dilakukan pre-test dan post-test sehingga peningkatan hasil belajar peserta didik sesudah menggunakan LKPD dapat terukur. Ketercapaian indikator keseluruhan dikatakan tuntas apabila memperoleh hasil $\geq 71 \%$. Rekapitulasi hasil ketercapaian indikator pada KD 3.9 dan 4.9 setelah menggunakan LKPD berbasis SSCS pada materi Arthropoda disajikan dalam Gambar 2.

Hasil belajar siswa diukur dengan lembar pretest dan post-test. Hasil belajar pre-test menunjukkan bahwa seluruh peserta didik tidak tuntas, sedangkan hasil belajar post-test didapatkan 20 peserta didik tuntas. Hasil bealajar pre-test dan post-test dihitung menggunakan perhitungan Gain Score untuk mengetahui peningkatan hasil belajar peserta didik. Gain Score didapatkan rata-rata $(\mathrm{g})$ sebesar 0,81 dan tergolong dalam kategori tinggi.

Tabel 1. Fitur-fitur LKPD berbasis SSCS materi Arthropoda

\begin{tabular}{ccl}
\hline No. & Fitur & \multicolumn{1}{c}{ Keterangan } \\
\hline $\mathbf{1}$ & Tahap Search & $\begin{array}{l}\text { Disajikan ilustrasi dan awetan anggota filum Arthropoda, peserta didik } \\
\text { dapat menganalisis permasalahan yang muncul pada ilustrasi dan } \\
\text { membuat rumusan masalah terkait ilustrasi yang telah dibacanya. } \\
\text { Bagian ini peserta didik memilih metode pemecahan masalah yakni } \\
\text { dengan melakukan pengamatan secara langsung dengan menggunakan } \\
\text { awetan anggota filum Arthropoda }\end{array}$ \\
$\mathbf{3}$ & Tahap Solve & $\begin{array}{l}\text { Bagian ini peserta didik menyusun data hasil pengamatan dan melakukan } \\
\text { pengklasifikasian anggota hewan filum Arthropoda yang telah diamati }\end{array}$ \\
$\mathbf{4}$ & Tahap Share & Bagian ini peserta didik mengkomunikasikan hasil pengamata \\
\hline
\end{tabular}

Tabel 2. Rekapitulasi validasi LKPD berbasis SSCS

\begin{tabular}{llcc}
\hline No. & \multicolumn{1}{c}{ Aspek Yang Dinilai } & Rata-rata Kelayakan Aspek (\%) & Kategori \\
\hline 1 & Penyajian & 4 & Sangat valid \\
2. & Isi & 3,5 & Sangat valid \\
3. & $\begin{array}{l}\text { Mendorong peserta didik untuk melatih } \\
\text { keterampilan proses sains }\end{array}$ & 4 & Sangat valid \\
& $\begin{array}{l}\text { Karakteristik pembelajaran dengan model } \\
\text { 4. }\end{array}$ & 3,5 & Sangat valid \\
5 & \begin{tabular}{l} 
Search, Solve, Create and Share (SSCS) \\
\multicolumn{1}{c}{ Modus }
\end{tabular} & 4 & Sangat valid \\
\hline
\end{tabular}


Tabel 3. Rekapitulasi aktivitas peserta didik menggunakan LKPD berbasis SSCS

\begin{tabular}{|c|c|c|}
\hline No & Aktivitas Siswa & $\begin{array}{c}\sum \text { Siswa Yang Beraktivitas } \\
(\%)\end{array}$ \\
\hline 1. & $\begin{array}{l}\text { Peserta didik membaca petunjuk penggunaan yang tercantum dalam } \\
\text { LKPD }\end{array}$ & 100 \\
\hline 2. & $\begin{array}{l}\text { Peserta didik membaca tujuan pembelajaran yang tercantum pada } \\
\text { LKPD }\end{array}$ & 95 \\
\hline 3. & $\begin{array}{l}\text { Peserta didik membaca materi pendahuluan tentang Arthropoda } \\
\text { dalam LKPD }\end{array}$ & 100 \\
\hline \multicolumn{3}{|c|}{ Tahap Search } \\
\hline 4. & $\begin{array}{l}\text { Peserta didik membaca ilustrasi mengenai hewan anggota Filum } \\
\text { Arthropoda }\end{array}$ & 100 \\
\hline 5. & Peserta didik melakukan pengamatan pada gambar & 100 \\
\hline 6. & $\begin{array}{l}\text { Peserta didik menganalisis masalah yang muncul dari ilustrasi dan } \\
\text { gambar tersebut }\end{array}$ & 90 \\
\hline \multicolumn{3}{|c|}{ Tahap Solve } \\
\hline 7. & Peserta didik berlatih memecahkan masalah & 100 \\
\hline 8. & $\begin{array}{l}\text { Peserta didik memecahkan masalah dengan metode pengamatan } \\
\text { secara langsung }\end{array}$ & 100 \\
\hline 9. & $\begin{array}{l}\text { Peserta didik melakukan pengamatan secara langsung berbagai } \\
\text { awetan hewan anggota Filum Arthropoda }\end{array}$ & 95 \\
\hline \multicolumn{3}{|c|}{ Tahap Create } \\
\hline 10. & $\begin{array}{l}\text { Peserta didik mengklasifikasi hewan amatan ke dalam tingkat kelas } \\
\text { hingga ordo setelah melakukan pengamatan }\end{array}$ & 80 \\
\hline 11. & Peserta didik menuliskan ciri khas yang dimiliki tiap kelas dan ordo & 100 \\
\hline 12. & $\begin{array}{l}\text { Peserta didik menentukan kelas hewan dan ordo Arthropoda } \\
\text { menggunakan kunci determinasi dan bantuan gambar }\end{array}$ & 90 \\
\hline \multicolumn{3}{|c|}{ Tahap Share } \\
\hline 13. & $\begin{array}{l}\text { Peserta didik dapat menuliskan laporan hasil pengamatan berupa } \\
\text { deskripsi. }\end{array}$ & 100 \\
\hline 14. & $\begin{array}{l}\text { Peserta didik dapat mengkomunikasikan hasil pengamatan di depan } \\
\text { kelas }\end{array}$ & 100 \\
\hline 15. & $\begin{array}{l}\text { Peserta didik dapat mengevaluasi hasil data yang diperoleh melalui } \\
\text { umpan balik dari guru }\end{array}$ & 100 \\
\hline $\begin{array}{l}\text { Rata } \\
\text { SSC }\end{array}$ & $\begin{array}{l}\text { rata Persentase Aktifitas Peserta didik menggunakan LKPD Berbasis } \\
\text { Materi Arthropoda }\end{array}$ & 96,66 \\
\hline
\end{tabular}

Tabel 4. Hasil Pengamatan Keterampilan Proses Sains Peserta Didik

\begin{tabular}{|c|c|c|}
\hline No. & Aktivitas Peserta Didik & $\begin{array}{c}\text { Persentase } \\
\text { Keaktifan } \\
(\%)\end{array}$ \\
\hline 1. & $\begin{array}{l}\text { Peserta didik menganalisis masalah yang muncul dari ilustrasi dan } \\
\text { gambar yang diberikan }\end{array}$ & 90 \\
\hline 2. & $\begin{array}{l}\text { Peserta didik melakukan pengamatan secara langsung berbagai } \\
\text { awetan hewan anggota Filum Arthropoda }\end{array}$ & 95 \\
\hline 3. & $\begin{array}{l}\text { Peserta didik mengklasifikasi hewan amatan ke dalam tingkat } \\
\text { kelas hingga ordo setelah melakukan pengamatan }\end{array}$ & 80 \\
\hline 4. & $\begin{array}{l}\text { Peserta didik dapat mengkomunikasikan hasil pengamatan di depan } \\
\text { kelas }\end{array}$ & 100 \\
\hline \multicolumn{2}{|c|}{$\begin{array}{l}\text { Rata-rata Persentase Respons Peserta didik menggunakan LKPD Berbasis } \\
\text { SSCS Materi Arthropoda }\end{array}$} & 91,25 \\
\hline
\end{tabular}

Tabel 5. Rekapitulasi Hasil respons peserta didik terhadap LKPD berbasis SSCS materi Arthropoda

\begin{tabular}{lll}
\hline No. & Sikap Peserta Didik & \multicolumn{1}{c}{$\begin{array}{c}\text { Peserta Didik } \\
(\%)\end{array}$} \\
\hline 1. & Isi & 98.57 \\
2. & Bahasa & 93.75 \\
3. & Penyajian & 98.75 \\
\hline
\end{tabular}




\begin{tabular}{llc}
\hline No. & Sikap Peserta Didik & $\begin{array}{c}\text { Peserta Didik } \\
(\%)\end{array}$ \\
\hline $4 . \quad$ Aspek Ketertarikan Peserta didik & 95 \\
$5 . \quad$ Kesesuaian dengan SSCS & 100 \\
\hline $\begin{array}{l}\text { Rata-rata Persentase Respons Peserta didik menggunakan LKPD } \\
\text { Berbasis SSCS Materi Arthropoda }\end{array}$ & 96.95 \\
\hline
\end{tabular}

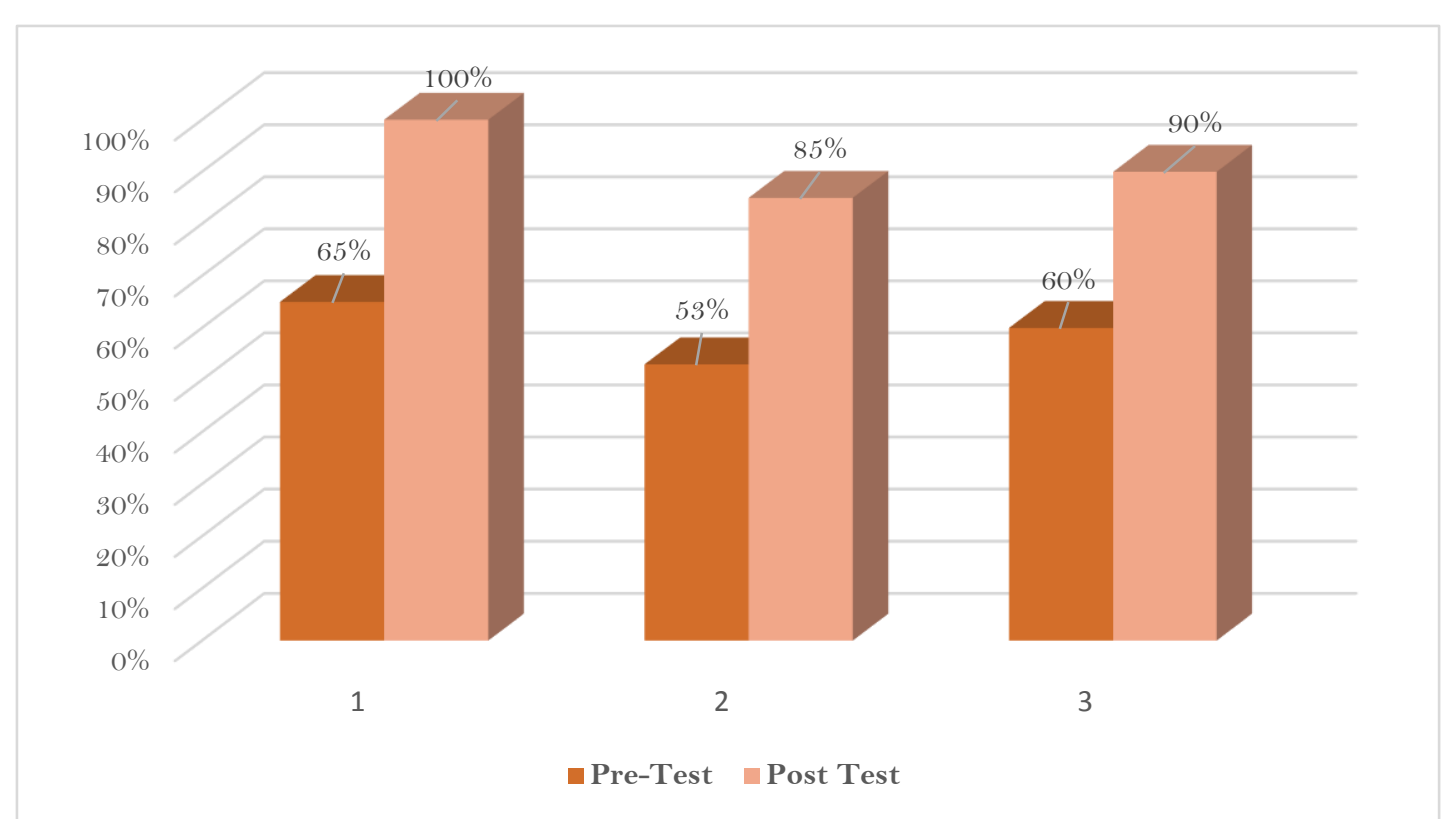

Gambar 2. Rekapitulasi data ketercapaian indikator pembelajaran setelah proses pembelajaran menggunakan LKPD berbasis SSCS pada materi Arthropoda

Keterangan:

1. Mengidentifikasi ciri-ciri umum yang teramati dari hewan filum Arthropoda berdasarkan lapisan tubuh, rongga tubuh, simetri tubuh dan reproduksi.

2. Mengklasifikasikan hewan filum Arthropoda ke dalam tingkat kelas

3. Memberi contoh hewan dari tiap kelas

Hasil belajar siswa diukur dengan lembar pre-test dan post-test. Hasil belajar pre-test menunjukkan bahwa seluruh peserta didik tidak tuntas, sedangkan hasil belajar post-test didapatkan 20 peserta didik tuntas. Secara keseluruhan hasil belajar post-test lebih tinggi dibandingkan dengan hasil belajar pre-test. Hasil bealajar pre-test dan post-test dihitung menggunakan perhtungan Gain Score untuk mengetahui peningkatan hasil belajar peserta didik. Gain Score didapatkan rata-rata (g) sebesar 0,81 dan tergolong dalam kategori tinggi.

Kelayakan LKPD berbasis SSCS materi Arthropoda berdasarkan validitas, kefektifan dan kepraktisan. Validitas ditinjau dari hasil validasi oleh ahli materi dan ahli pendidikan. Keefektifan media dan LKPD berbasis SSCS materi Arthropoda ditinjau dari hasil belajar dan angket respons peserta didik. Kepraktisan LKPD berbasis SSCS materi Arthropoda ditinjau dari aktivitas peserta didik.
Berdasarkan hasil validasi (Tabel 2) diketahui bahwa LKPD yang dikembangkan memiliki modus 4 dan termasuk dalam kategori sangat valid. Oleh karena itu LKPD berbasis SSCS dapat diujicobakan di sekolah. Kelayakan tersebut didapatkan berdasarkan 5 aspek penilaian terhadap LKPD berbasis SSCS yaitu terdiri dari aspek penyajian, aspek kelayakan isi, aspek keterampilan proses peserta didik, aspek karakteristik dengan model pembelajaran SSCS, dan aspek kebahasaan.

Kepraktisan LKPD berbasis SSCS materi Arthropoda untuk melatihkan keterampilan proses ditinjau berdasarkan aktivitas peserta didik dan hambatan yang dihadapi peserta didik saat proses pembelajaran menggunakan LKPD. Aktivitas peserta didik diamati pada saat peserta didik menggunakan LKPD berbasis SSCS materi Arthropoda. Aktivitas yang diamati terdiri dari lima belas aspek dengan rata-rata nilai keaktifan peserta didik sebesar 96,66\% (Tabel 3) dengan kategori praktis. 
Aktivitas yang dinilai merupakan gabungan dari sintaks model pembelajaran SSCS dan sintaks dari keterampilan proses. Pada tahap pertama, yaitu tahap Search, kegiatan yang dilakukan peserta didik yaitu membaca ilustrasi mengenai anggota filum Arthropoda dengan topik Insekta dan Arachnida, peserta didik dapat menemukan permasalahan yang muncul dari ilustrasi tersebut. Tahap tersebut memperoleh rata-rata sebesar $96,66 \%$ yang termasuk dalam kategori praktis. Hal ini sesuai dengan hasil penelitian Iswantini \& Purnomo (2017) membaca artikel dapat membantu peserta didik untuk berpikir secara sistematis dan melatih keterampilan penyelidikan. Peserta didik dapat belajar melalui penemuan sehingga mereka mampu menemukan sendiri dan berusaha untuk mencari pemecahan masalah yang didukung oleh pengetahuan yang telah dimilikinya.

Tahap SSCS selanjutnya yaitu tahap Solve yang memperoleh rata-rata sebesar $98,33 \%$ yang termasuk dalam kategori praktis. Pada tahap ini kegiatan yang dilakukan yakni memilih metode untuk memecahkan masalah dengan melakukan metode pengamatan secara langsung. Hal ini sejalan dengan teori belajar Vygotsky yang menyatakan bahwa perkembangan intelektual peserta didik mampu terjadi apabila dalam proses pembelajaran peserta didik berhadapan dengan suatu masalah dan mereka akan berusaha untuk memecahkan masalah tersebut (Vygotsky, 1978). Kegiatan mengamati atau kegiatan investigasi juga dapat membantu melatih keterampilan proses yang dimiliki peserta didik karena kegiatan mengamati merupakan keterampilan dasar yang dibutuhkan dalam proses memperoleh ilmu pengetahuan (Atmojo, 2012).

Tahap SSCS selanjutnya yaitu tahap Create yang memperoleh rata-rata sebesar 90\% yang termasuk dalam kategori praktis. Pada tahap ini kegiatan yang dilakukan yakni melakukan penyusunan data hasil pengamatan awetan hewan anggota filum Arthropoda dan pengklasifikasian hewan anggota filum Arthropoda. Klasifikasi merupakan hal yang penting untuk dapat mengetahui bahwa satu ciri yang dimiliki suatu objek juga dimiliki oleh objek yang lain (Duruk, dkk., 2017). Kegiatan pada tahap ini sejalan dengan pendapat Ausubel mengenai pembelajaran bermakna yakni dalam proses pembelajaran informasi baru yang didapatkan peserta didik dihubungkan dengan struktur kognitif yang telah dimiliki peserta didik (Ausubel, 1999).

Tahap yang terakhir yaitu Share yakni mengkomunikasikan hasil yang diperoleh dari pengamatan guna sebagai jawaban dari masalah, tahap tersebut memperoleh rata-rata sebesar $100 \%$. Menurut Ibrahim (2010), menyatakan bahwa proses mengkomunikasi dapat berupa pendeskripsian hasil pengamatan, merangkum informasi dalam bacaan dan menyajikan data dalam bentuk grafik atau tabel. Hal tersebut sejalan dengan pendapat Fraser dkk. (2011) bahwa keterampilan mengkomunikasikan merupakan proses penyampaian infomasi secara lisan maupun tulisan yang berupa deskripsi, grafik, gambar, serta hasil pengamatan yang lain.

Berdasarkan (Tabel 3) dapat diketahui bahwa keterampilan proses peserta didik terhadap LKPD berbasis SSCS pada materi Arthropoda yang dikembangkan termasuk dalam kategori aktif yaitu sebesar $91,25 \%$ atau dengan kata lain peserta didik telah terlatih dalam keterampilan proses yang diajarkan pada LKPD berbasis SSCS. Hal ini sesuai dengan hasil validasi yang memperoleh modus sebesar 4 yang termasuk ke dalam kategori sangat valid dan sesuai dengan pengamatan keterampilan proses peserta didik yang termasuk dalam kategori aktif.

Berdasarkan Tabel 4 dapat diketahui bahwa keterampilan proses sains peserta didik terhadap LKPD berbasis SSCS pada materi Arthropoda yang dikembangkan termasuk dalam kategori aktif yaitu sebesar $91,25 \%$ artinya peserta didik dapat dilatih keterampilan prosesnya melalui penggunaan LKPD berbasis SSCS. Hal ini didukung dengan hasil validasi yang memperoleh modus sebesar 4 yang termasuk ke dalam kategori sangat valid dan sesuai dengan pengamatan aktivitas peserta didik yang aktif dalam menggunakan LKPD.

Respons peserta didik didapatkan melalui angket respons peserta didik yang diberikan kepada peserta didik setelah kegiatan pembelajaran dengan menggunakan LKPD berbasis Search, Solve, Create and Share (SSCS) pada materi Arthropoda untuk melatihkan keterampilan proses. Pada angket respons peserta didik terdapat beberapa kriteria yang ditanyakan yaitu kriteria isi, bahasa, penyajian, dan kesesuaian dengan SSCS pada LKPD yang dikembangkan. Berdasarkan hasil yang diperoleh pada (Tabel 5) dapat diketahui bahwa respons peserta didik terhadap LKPD berbasis SSCS pada materi Arthropoda untuk melatihkan keterampilan proses yang dikembangkan termasuk dalam kategori sangat praktis yaitu sebesar $96.95 \%$ atau dengan kata lain peserta didik memberikan respons positif. Hal ini sesuai dengan pendapat Pinasthika dkk. (2013) 
yang menyatakan bahwa penggunaan LKS pada kegiatan pembelajaran dapat mempermudah peserta didik dalam memahami materi, di mana peserta didik dapat menemukan konsep-konsep sesuai panduan dalam LKPD.

Keefektifan LKPD yang dikembangkan ditinjau dari ketercapaian indikator dan hasil belajar peserta didik. Indikator yang dinilai dalam penelitian ini yaitu indikator pengetahuan dan keterampilan yang mengacu pada KD 3.9 dan KD 4.9. Ketercapaian indikator peserta didik diketahui melalui hasil pre-test dan post-test. Dengan pre-test dan post-test maka diketahui adanya peningkatan hasil belajar peserta didik sesudah menggunakan LKPD berbasis SSCS pada materi Arthropoda untuk melatihkan keterampilan proses. Peserta didik dikatakan tuntas karena mendapat nilai lebih besar dari menurut KKM mata pelajaran biologi kelas X MAN Sidoarjo yaitu sebesar 75 .

Berdasarkan (Tabel 6) dapat diketahui bahwa ketuntasan indikator pembelajaran berdasar nilai pre-test pada KD 3.9 terdapat tiga indikator yaitu indikator 3.9.1 mengidentifikasi ciri-ciri umum yang teramati dari hewan filum Arthropoda dengan ketuntasan sebesar 65\%, indikator 3.9.2 mengklasifikasikan hewan filum Arthropoda ke dalam tingkat kelas dengan ketuntasan sebesar 53\% dan indikator 3.9.3 memberi contoh hewan dari tiap kelas dengan ketuntasan sebesar 60\%. Secara keseluruhan peserta didik belum tuntas dalam pre-test karena nilai yang didapatkan peserta didik kurang dari KKM yang telah di tentukan. Sedangkan nilai post-test peserta didik secara keseluruhan telah melebihi KKM $(\geq 75)$. Hal ini menunjukkan bahwa seluruh peserta didik telah tuntas sehingga ketuntasannya sebesar 100\%.

Peningkatan nilai peserta didik membuktikan bahwa penggunaan LKPD berbasis SSCS pada materi Arthropoda untuk melatihkan keterampilan proses selama kegiatan pembelajaran dapat dikatakan efektif. Hal ini disebabkan selama proses pembelajaran peserta didik dituntut untuk aktif dan memberikan kebebasan kepada siswa untuk mengembangkan kreativitas dan keterampilan berpikir dalam rangka memperoleh pemahaman ilmu dengan melakukan penyelidikan dan mencari solusi dari permasalahan yang ada (Utami, 2011). Selain itu, menurut Febriyanti (2014) menyatakan bahwa model pembelajaran SSCS yang diterapkan dalam pembelajaran mampu dengan mudah meningkatkan keterampilan proses sains karena dengan belajar dari permasalahan akan membuat peserta didik termotivasi untuk memecahkan masalah dan berlatih untuk menemukan solusi dari masalah.

Peningkatan nilai peserta didik kemudian dihitung menggunakan gain score untuk mengetahui peningkatan nilai pre-test dan post-test. Hasil perhitungan $\mathrm{N}$-gain menunjukkan hasil bahwa 18 peserta didik (90\%) memperoleh skor Ngain dengan kategori tinggi dan dua peserta didik (12,5\%) memperoleh skor $\mathrm{N}$-gain dengan kategori sedang. Hal tersebut menunjukkan bahwa semua peserta didik mengalami peningkatan nilai setelah menggunakan LKPD berbasis SSCS pada materi Arthropoda. Peningkatan nilai yang didapatkan peserta didik membuktikan bahwa LKPD yang dikembangkan terbukti dapat melatihkan keterampilan proses peserta didik.

\section{SIMPULAN}

Berdasarkan penelitian yang telah dilakukan, simpulan dari penelitian ini adalah telah dikembangkan Lembar Kerja Peserta Didik (LKPD) Berbasis Search, Solve, Create and Share (SSCS) pada materi Arthropoda untuk Melatihkan Keterampilan Proses yang layak secara teoritis ditinjau berdasarkan tingkat validitas dan kelayakan empiris ditinjau berdasarkan tingkat kepraktisan dan keefektifannya. Validitas LKPD ini memperoleh modus dengan kategori sangat layak; Kepraktisan memperoleh tingkat kepraktisan aktivitas keterampilan proses dan respons peserta didik masing-masing sebesar 96,66\% dan 96,95\%; Keefektifan memperoleh hasil sangat efektif dengan ketercapaian indikator dan ketuntasan hasil belajar peserta didik sebesar $100 \%$.

\section{UCAPAN TERIMAKASIH}

Terima kasih kepada Prof. Dr. Muslimin Ibrahim, M.Pd. selaku dosen penguji yang telah memberikan kritik serta saran untuk perbaikan penyusunan skripsi Pengembangan LKPD berbasis SSCS, Prof. Dr. Endang Susantini, M.Pd. selaku validator ahli materi yang juga memberikan kritik serta saran untuk perbaikan penyusunan skripsi Pengembangan LKPD berbasis SSCS serta pihak MAN Sidoarjo.

\section{DAFTAR PUSTAKA}

Atmojo, S.E. (2012). Profil Keterampilan Proses Sains dan Apresiasi Peserta didik Terhadap Profesi Pengrajin Tempe dalam Pembelajaran Ipa Berpendekatan Etnosains. Juornal Unnes. 1 (2) : 115-122. 
Ausubel, David P. (1999). The Use of Advanced Organizersmin the Learning and Retention of Meaningful Verbal Material. Journal of educational psychology. $51:$ 267-272.

Duruk, U., Abuzer, A., Ceylan, D., \& Fatma, G. (2017). Examining the Learning Outcomes Included in the Turkish Science Curriculum in Terms of Science Process Skills: A Document Analysis with Standards-Based Assesment. International Journal Of Enviromental \& Science Education. 12 (2) : 117142 .

Febriyanti, D., Ilyas, S. Nurmaliah, C. (2014). Peningkatan Keterampilan Generik Sains Melalui Penerapan Model SSCS (Search, Solve, Create And Share) pada Materi Mengklasifikasikan Makhluk Hidup di MTsN Model Banda Aceh. Jurnal Biologi Edukasi. 6 (2) : 43-47.

Fraser, P., \& Abder. (2010). Teaching Emerging Scientist Fostering Scientific Inquiry with Diverse Learner in Grade K-2. Boston: Pearson Education Inc.

Ibrahim, M. 2010. Dasar-Dasar Proses Belajar Mengajar. Surabaya: University Press.

Iswantini, W \& Purnomo, T. (2017). Validitas Lembar Kegiatan Peserta didik Berbasis Inkuiri pada
Materi Pencemaran Lingkungan untuk Melatihkan Literasi Sains Peserta didik Kelas X SMA. BioEdu. 6 (3,) : 344-352

Jerome, S. B. (1960). The Process of Education. Harvard University Press Cambridge.

Lartson, C.A. (2013). Effects of Design-Based Science Instruction on Science Problem-Solving Competency Among Different Groups of High-School Traditional Chemistry Students. Thesis. University of Colorado

Lepiyanto, A. P.S.A. (2016). Pengembangan Lembar Kegiatan Peserta Didik (LKPD) Berbasis Scientific Approach Peserta didik SMS Kelas X pada Materi Fungi. Jurnal Pendidikan Biologi Universitas Muhammadiyah Metro. 7 (1).

Pinasthika, C. Haryono, T. Prastiwi, S. M. 2013. Aktivitas Belajar Peserta didik Sekolah Menengah Atas Menggunakan LKS Berbasis WEB Materi Kingdom Animalia. Jurnal Bioedu Unesa. 2: 293298.

Utami, R.P. 2011. Pengaruh Model Pembelajaran Search Solve Create and Share (SSCS) dan Problem Based Learning (PBI) Terhadap Prestasi Belajar dan Kreativitas Peserta didik. Jurnal Bioedukasi. 4 (2): 57-71. 